

\title{
How can global conventions for biodiversity and ecosystem services guide local conservation actions?
}

Ilse Geijzendorffer, Astrid Ja van Teeffelen, Hilary Allison, Daniela Braun,

Katherine Horgan, Maitane Iturrate-Garcia, Maria João Santos, Loïc

Pellissier, Anne-Hélène Prieur-Richard, Simone Quatrini, et al.

\section{To cite this version:}

Ilse Geijzendorffer, Astrid Ja van Teeffelen, Hilary Allison, Daniela Braun, Katherine Horgan, et al.. How can global conventions for biodiversity and ecosystem services guide local conservation actions?. Current Opinion in Environmental Sustainability, 2017, 29, pp.145 - 150. 10.1016/j.cosust.2017.12.011 . hal-01783574

\section{HAL Id: hal-01783574 \\ https://hal.science/hal-01783574}

Submitted on 2 May 2018

HAL is a multi-disciplinary open access archive for the deposit and dissemination of scientific research documents, whether they are published or not. The documents may come from teaching and research institutions in France or abroad, or from public or private research centers.
L'archive ouverte pluridisciplinaire HAL, est destinée au dépôt et à la diffusion de documents scientifiques de niveau recherche, publiés ou non, émanant des établissements d'enseignement et de recherche français ou étrangers, des laboratoires publics ou privés. 


\section{How can global conventions for biodiversity and ecosystem services guide local conservation actions?}

Ilse R Geijzendorffer ${ }^{1}$, Astrid JA van Teeffelen ${ }^{2}$, Hilary Allison ${ }^{3}$, Daniela Braun ${ }^{4}$, Katherine Horgan ${ }^{5}$, Maitane Iturrate-Garcia ${ }^{5}$, Maria Joâo Santos $^{6}$, Loïc Pellissier ${ }^{7,8}$, Anne-Hélène Prieur-Richard ${ }^{9}$, Simone Quatrini ${ }^{7,8,10}$, Shoko Sakai ${ }^{11}$ and Debra Zuppinger-Dingley ${ }^{5}$

\section{Addresses}

1 Tour du Valat, Research Institute for the Conservation of Mediterranean Wetlands, Sambuc, 13200 Arles, France

2 Environmental Geography Group, Department of Earth Sciences, Faculty of Science, Vrije Universiteit Amsterdam, De Boelelaan 1087, 1081 HV Amsterdam, The Netherlands

3 UN Environment World Conservation Monitoring Centre (UNEP-WCMC), 219c Huntingdon Road, Cambridge CB3 ODL, UK

4 Remote Sensing Laboratories, University of Zurich, Winterthurerstrasse 190, 8057 Zürich, Switzerland

5 URPP on Global Change and Biodiversity, Department of Evolutionary Biology and Environmental Studies, University of Zurich, Winterthurerstrasse 190, 8057 Zürich, Switzerland

${ }^{6}$ Copernicus Institute of Sustainable Development, Utrecht University, Heidelberglaan 2, P.O. Box 80115, 3508 TC Utrecht,

The Netherlands

7 Landscape Ecology, Department of Environmental Systems Science, ETH Zürich, 8092 Zürich, Switzerland

${ }^{8}$ Swiss Federal Research Institute WSL, 8903 Birmensdorf, Switzerland

9 Future Earth, Montreal Global Hub, Suite 1020, 1250 Guy Street, Montreal, Quebec, Canada

10 United Nations Convention to Combat Desertification (UNCCD), P.O. Box 260129, 53153 Bonn, Germany

11 Center for Ecological Research, Kyoto University, Otsu 520-2113, Japan

Corresponding author: Geijzendorffer, Ilse R (ilse@tourduvalat.org)

\section{How to Cite}

Geijzendorffer I.R., van Teeffelen A.J., Allison H., Braun D., Horgan K., Iturrate-Garcia M., Santos M.J., Pellissier L., Prieur-Richard A.-H., Quatrini S., Sakai S., Zuppinger-Dingley D. 2017. How can global conventions for biodiversity and ecosystem services guide local conservation actions? Current Opinion in Environmental Sustainability 29:145-150. doi: 10.1016/j.cosust.2017.12.011, Accepted: 31 December 2017

With global science-policy conventions for biodiversity and ecosystem services in place, much effort goes into monitoring and reporting on the progress toward policy targets. As conservation actions happen locally, can such global monitoring and reporting efforts effectively guide conservation. actions at subnational level? In this paper we explore three different perspectives: policy reporting for policy implementation; scientific knowledge for empowerment and actions; and from past trends to influencing the future. Using these three perspectives, we identify ways forward for both decision makers and scientists on how to engage, inform and empower a larger diversity of actors who make decisions on the future of biodiversity and ecosystem services at multiple scales

Without doubt, scientific understanding of why and where biodiversity and ecological resilience are degrading is advancing $[1 ", 2]$. In addition, there is enormous investment and engagement by both decision makers and scientists to maintain and raise the environmental stakes on international policy agendas in the face of worldwide economic, social and political challenges. Global biodiversity targets as set by the signatories to the Convention on Biological Diversity in 2010 (the Aichi targets), the 2013 European Union strategy on adaptation to climate change, and the Sustainable Development Goals, require short to medium term action in translating such targets to local conservation actions [e.g. 3], for instance at the level of protected areas, watersheds or a village [4].

With the first thematic, regional and global assessment reports of the Intergovernmental Science-Policy Platform on Biodiversity and Ecosystem Services (IPBES) being published [5,6] or steadily advancing, it is timely to reflect on how the substantial scientific and political investments in monitoring and reporting on progress toward global biodiversity and ecosystem service targets can be used effectively for conservation actions. Taking the perspective of societal actors faced with subnational or site based conservation challenges, we explore the possible guidance that these global initiatives may provide. As the ultimate objective is to decrease biodiversity degradation [7], frequent back casting of the extent of biodiversity and ecosystem services loss for reporting does not necessarily provide guidance on what to do differently to curb downward trends in the future [8"]. A different approach is therefore required to obtain and use information from global conventions to enhance the effectiveness of societal actors in addressing local biodiversity degradation. A lack of information is only one of many factors mentioned when listing impediments to the impact of local conservation actions. Empowerment of local actors, multi-actor mobilization and addressing the impaired effectiveness of governance are measures that have been suggested as steps toward curbing current biodiversity trends $[9,10 ", 11-13]$, steps which cannot be taken by decision makers, scientists or NGOs in isolation or bilaterally.

In this paper we reflect on: policy reporting for policy implementation; scientific knowledge for empowerment and actions; and from past trends to influencing the future. From these three perspectives, we identify ways forward for both decision makers and scientists on how to engage with, inform and empower a larger diversity of actors that take decisions on the future of biodiversity and ecosystem services at local scales. 


\section{Policy reporting for policy implementation}

From the experience of the Intergovernmental Panel on Climate Change (IPCC) it is evident that the road from developing a shared perception of the problem to assessing challenges and identifying solutions for the future is long and paved with strategic and political pitfalls [14]. With biodiversity and its relation to ecosystem services being even more complex to understand than climate change, developing a shared perception and understanding of the problems around biodiversity and its associated services between scientists, decision makers and societal actors will be at least equally challenging [15'].

Biodiversity trend assessments with comparable methods to increase the credibility of the observed trends have emerged over time [e.g. Convention on Biological Diversity, 16] and many indicators and trends have been identified [e.g. 17-22]. The recent surge of interest in ecosystem services has similarly led to monitoring and reporting efforts at all spatial and institutional scales [e.g. 23-25; the ongoing Regional and Global IPBES assessments]. Biodiversity and ecosystem assessments still lack systematically recorded data and indicator use is incon sistent, making it difficult to conduct trend analyses over time and across regions. In the absence of this, the integration and harmonization of different kinds of data is one of the priorities in developing subnational management plans, for example for the state of New South Wales, Australia, in mitigating the impacts of climate change on biodiversity [3].

Although it is difficult to assess the realized implementation of international conventions across all the different actors who take biodiversity and ecosystem service related decisions, the credibility and value of comprehen sive sciencepolicy-platforms, such as IPBES, partly depend on whether their findings are successfully implemented [1"]. In recent decades, internationally shared objectives have been transformed into global initiatives, such as sustainable development [26] or the protection of specific species and ecosystems (e.g. Ramsar [27]; Biodiversity Action Plans or Convention on Illegal Trade in Endangered species: www.worldwildlife.org/pages/cites). Without national and regional implementation commitments, it is difficult at a local level to anticipate which objectives and actions will be endorsed by national governments in the longer-term. Simultaneously, progress made at a local scale may not be recognized at national or global scales [28'].

Common assumptions are that low efficacy of biodiversity conservation management can be improved by filling existing knowledge gaps [29"] or increasing the protection status. Although local actors may indeed perceive a lack of information (for instance the exact way climate change is going affect biodiversity at their protected areas [e.g. 3]), this is rarely the only or most important barrier to local conservation action [e.g. 12]. Take for instance, the impact of stakeholder involvement in policy implementation [10",13,30]. In addition, it is becoming increasingly clear that protection of areas is not sufficient to change biodiversity degradation trends [7,8"]. Despite governments making longterm commitments to the conservation of biodiversity, ecosystem services and related natural resources, such commitments can be threatened by changes in power, and a protection status previously approved by a government may be changed or simply terminated [e.g. 31]. This is complemented by a growing trend of attributing limited value or credibility to scientific evidence in political debates, which affects policy development and implementation [32].

Furthermore, taking into consideration some multinational companies today generate more profit than the Gross Domestic Products (GDP) of entire countries, it would not be fair nor realistic to expect or request governments to single-handedly protect biodiversity. Assessments and recommendations, such as those delivered through IPBES, should therefore not solely focus on decision makers in governments, but also on the multiple actors involved in real world decisions on biodiversity and implementation. Where reports have their limitations, adding clickable maps or additional data repositories can offer a downscaling of report results that facilitates use by mayors, urban planners, NGOs, community leaders, business executives, investors and citizens. Following up on the objective of IPBES to provide capacity building [Item 6 (a) of 33], concrete actions could include the supply of expertise to translate global recommendations into concrete approaches for management plans. The involvement of different actors is essential because their roles in safeguarding ecosystem services (e.g. food production, water purification) and biodiversity (e.g. for nature related tourism) are different from the role government bodies play (e.g. to define and protect national parks). For instance, the role that the private sector could play in the financing and implementation of the Sustainable Development agenda has been clearly articulated in the Addis Ababa Action Agenda [34].

\section{Scientific knowledge for empowerment and actions}

Many scientific publications identify and call for harmonized biodiversity and ecosystem services monitoring schemes for policy reporting [e.g. 35,36]. However, recommendations for concrete actions, which would help non-governmental actors' implementation of findings from these reports at a local level, are hard to find. For instance the kn owledge that management decisions result in trade-offs among ecosystem services $[37,38]$ has yet to be transformed into concrete guidelines which go beyond simple optimization and effectively help navigate trade-offs at local scales. The 
implementation of a reserve protection status can be detrimental to local peoples' access and recognition of their cultural and natural heritage [13].

Information which leads to new or adaptation of existing conservation actions is not identical to the information required for monitoring and reporting. Notably, indicators need to be sensitive enough to detect change [20] at a rate at which decisions can be triggered [39"]. This is not an easy endeavor when monitoring data of pressures on biodiversity and ecosystem services is often missing [40"]. There are, however, examples where scientific initiatives are successfully and systematically monitoring changes over time. Notably the Global Forest Watch initiative (www.globalforestwatch.org/) has increased the effectiveness of local law enforcement on illegal logging, by providing open access to frequently updated earth observation images of forest cover.

Whereas citizens are increasingly considered as a credible source of observations and data for scientific studies and policy reports [41,42], the potential impact citizens have on daily decisions about natural resources and biodiversity is much less acknowledged or understood. International reviews and place-based research [10",43',44'] have demonstrated that the involvement of local actors in biodiversity knowledge development stimulates a much quicker uptake of recommendations than only following top-down governance implementation. More knowledge about how local citizen engagement and empowerment can be increased (e.g. through votes, changing consumption patterns or supporting NGOs) could diversify conservation strategies and result in positive impacts for biodiversity and ecosystem services. For practitioners, an improved quantification of biodiversity decline is less likely to lead to adaptation of management decisions than information on how to prepare for and mitigate the impacts of land use and climate change [e.g. 44']. A greater understanding of which kind of information empowers citizens and results in positive impacts for biodiversity and ecosystem services could be obtained through long-term involvement of stakeholders in place based research [28'].

Some of today's largest nature conservation organizations began as a result of an integrated approach of interests of citizens and private funding to safeguard nature, some-times together with, or in opposition to national governments (see for example the importance of collaboration between decision makers, scientists and hunters in the birth of WWF, or the creation of Donana National Park [45]). Currently ways to influence general adherence to environmental objectives have partly changed (e.g. social media is increasingly important for creating international visibility for progress as well as breaches of international agreements), creating a wider range of options for a diversity of actors to connect and act. The successful Turkish Flamingo Campaign (2012-2013), for instance, predominantly oriented its outreach directly at the general public, journalists and local actors (Birdlife Turkey, unpublished data).

The industry and banking sectors are often portrayed as exerting multiple pressures upon the environment, but events in 2017, when CEOs of multinationals urged the President of the USA to uphold its commitment to the 2015 Paris Climate Accord, indicate they can be potential allies. This does not naively assume that con-cern for the future of the planet is a top priority for industry. It does however, indicate that economic and innovation interests can, and some say should, mobilize important support ([46], https://www.nature. org/about-us/working-with-companies/index.html). Similarly, the financial sector, especially the World Bank, is maturing its environmental impact assessments. Such assessments are obligatory for large infrastructure projects and are gradually being introduced in many responsible investment domains, for example through the International Finance Corporation's (IFC) performance standards (http://www.ifc.org/sustainability). Having relevant knowledge can improve impact assessments (e.g. http:// ec.europa.eu/environment/eia/pdf/EIA\%20Guidance. pdf) and lead to credible monitoring of impacts and evidencebased mitigation. Scientists can contribute relevant knowledge by increasing data and knowledge availability and developing credible assessment tools for more transparent and evidence-based impact assessments [1"]. Although there are ever-present concerns about conflicts of interest [47], environmental researchers should not (be asked to) close the door on collaboration with industries that genuinely strive to minimize their impact.

\section{From past trends to influencing the future}

Biodiversity and ecosystem service reports for decision makers yield valuable information on past trends [30,48] and contribute support for international decision making and agreements. However, data on past trends at national and international spatial scales does not inform local actors on how to act now to curb downward trends [39,1]. In addition, the implementation of policy measures is often not accompanied by a monitoring of their impact, leaving little information to evaluate effectiveness for future reference [e.g. see the EU Common Agricultural Policy 49]. Important information on the impact and timing of possible actions could come from future projections or backcasting from a desired outlook. Science-policy platforms can stimulate scenario building, but biodiversity scenario studies have focused increasingly on single pressures (notably climate change [27]) whereas comprehensive studies incorporating multiple factors including changes in land cover and land use intensity, are rare [50]. For multiple driver scenarios, many barriers have to be overcome, such as data deficiencies (e.g. on land use intensity [51]), mismatches in time horizons between climate change and socio-economic scenarios [50] and an absence of common scenarios for habitat 
fragmentation and land cover change [44']. Moreover, generally large-scale model outputs are used, which often do not provide information on local priorities. It would be important to assess which actions undertaken by which actors in the social-ecological landscape have the most impact. The IPBES Modeling and Scenario expert group and the scientific community are taking first steps to address this challenge [5] by, for instance similarly to the IPCC climate scenarios, developing biodiversity scenario narratives that could be applied to different spatial scales. Although co-development of biodiversity scenarios does take place [e.g. 52,53], it is relatively rare and the development of coherent scenarios across spatial scales remains a challenge which has not yet been solved.

\section{Conclusion}

To prevent a further decline of biodiversity and to ensure the long-term sustainable use of the ecosystem services biodiversity provides, decision makers and scientists need to diversify their strategies. Communication of results has to be timely, include concrete recommendations at relevant spatial scales and be oriented to a wider range of actors who make decisions on biodiversity actions. Information and communication can be complemented with concrete actions to facilitate the uptake of results at subnational level while simultaneously addressing barriers for biodiversity conservation efficacy. This requires a clear vision of what can be changed to improve the future, which may build on, but cannot come solely from an improved quantification of past trends.

\section{Conflicts of interest}

None.

\section{Acknowledgements}

Authors are grateful for the discussion opportunity created at the 'Global Change and Biodiversity' conference organized by the University of Zürich Research Priority Programme on Global Change and Biodiversity, where the work for this manuscript was initiated. Funders of the conference are: Congressi Stefano Franscini, ETHZ, Swiss National Science Foundation and the University of Zurich. Reflections presented in this paper contribute to the ongoing work in the GEO BON Policy Taskforce. IG's contribution was partly funded by the ECOPOTENTIAL project under the European Union's Horizon 2020 research and innovation programme (Grant agreement No 641762).

\section{References and recommended reading}

Papers of particular interest, published within the period of review, have been highlighted as:

- of special interest

•. of outstanding interest

1. • Guerry AD, Polasky S, Lubchenco J, Chaplin-Kramer R, Daily GC, Griffin R, Ruckelshaus M, Bateman IJ, Duraiappah A, Elmqvist T et al.: Natural capital and ecosystem services informing decisions: from promise to practice. Proc Natl Acad Sci U S A 2015, 112:7348-7355.

Authors identify key challenges for the inclusion of ecosystem services in decision-making, the progress made at national scale and the scientific knowledge gaps that should be addressed.

2. Ceballos G, Ehrlich PR, Dirzo R: Biological annihilation via the ongoing sixth mass extinction signaled by vertebrate population losses and declines. Proc Natl Acad Sci U S A 2017 http://dx.doi.org/10.1073/pnas.1704949114.

3. Department of Environment, Climate Change and Water NSW (DECCW): Priorities for Biodiversity Adaptation to Climate Change. Department of Environment, Climate Change and Water NSW; 2010.

4. Brooks TM: Global biodiversity conservation priorities. Science 2006, 313:58-61.

5. IPBES: In The Methodological Assessment Report on Scenarios and Models of Biodiversity and Ecosystem Services. Edited by Ferrier S, Ninan KN, Leadley P, Alkemade R, Acosta LA, Akç akaya HR, Brotons L, Cheung WWL, Christensen V, Harhash KA, Kabubo-Mariara J, Lundquist C, Obersteiner M, Pereira HM, Peterson G, Pichs-Madruga R, Ravindranath N, Rondinini C, Wintle BA. 2016.

6. IPBES: In Summary for Policymakers of the Assessment Report of the Intergovernmental Science-Policy Platform on Biodiversity and Ecosystem Services on Pollinators, Pollination and Food Production. Edited by Potts SG, Imperatriz-Fonseca VL, Ngo HT, Biesmeijer JC, Breeze TD, Dicks LV, Garibaldi LA, Hill R, Settele J, Vanbergen AJ, Aizen MA, Cunningham SA, Eardley C, Freitas BM, Gallai N, Kevan PG, Kovâcs-Hostyânszki A, Kwapong PK, Li J, Li X, Martins DJ, Nates-Parra G, Pettis JS, Rader R, Viana BF. 2016.

7. Tittensor DP, Walpole M, Hill SLL, Boyce DG, Britten GL, Burgess ND, Butchart SHM, Leadley PW, Regan EC, Alkemade R et al.: A mid-term analysis of progress toward international biodiversity targets. Science 2014, 346:241-244.

8. •-Lindenmayer DB, Piggott MP, Wintle BA: Counting the books while the library burns: why conservation monitoring programs need a plan for action. Front Ecol Environ 2013, 11:549-555.

The authors successfully argue that current species monitoring schemes are predominantly focused on detecting trends in the past rather than informing conservation management decisions that are supposed to counter biodiversity decline.

9. Amano T, Sutherland WJ: Four barriers to the global understanding of biodiversity conservation: wealth, language, geographical location and security. Proc R Soc B: Biol Sci 2013, 280:20122649.

10. •-Danielsen F, Burgess ND, Jensen PM, Pirhofer-Walzl K: Environmental monitoring: the scale and speed of implementation varies according to the degree of peoples involvement. J Appl Ecol 2010, 47:1166-1168.

An innovative study that demonstrates that involvement of people at village scale is the quickest manner for policy intentions to be included in management decisions on local resource utilization.

11. Hutton J, Adams WM, Murombedzi JC: Back to the barriers? Changing narratives in biodiversity conservation. Forum Dev Stud 2005, 32:341-370. 
12. Mcleod E, Szuster B, Hinkel J, Tompkins EL, Marshall N, Downing T, Wongbusarakum S, Patwardhan A, Hamza M, Anderson $C$ et al.: Conservation organizations need to consider adaptive capacity: Why local input matters. Conserv Lett 2016, 9:351360 .

13. Méndez-L6pez ME, Garcia-Frapolli E, Pritchard DJ, Sânchez Gonzâlez MC, Ruiz-Mallén I, Porter-Bolland L, Reyes-Garcia V: Local participation in biodiversity conservation initiatives: a comparative analysis of different models in South East Mexico. $J$ Environ Manag 2014, 145:321-329.

14. Bolin B: A History of the Science and Politics of Climate Change: The Role of the Intergovernmental Panel on Climate Change. Cambridge University Press; 2007.

15. • Brooks TM, Lamoreux JF, Sober6n J: IPBES 74 IPCC. Trends Ecol Evol 2014, 29:543-545.

A compelling paper which draws the parallel between IPBES and IPCC from scientific as well political and structural perspectives, to demonstrate the additional challenges biodiversity experts face.

16. Secretariat of the Convention on Biological Diversity, United Nations Environment Programme (Eds): Global Biodiversity Outlook 4: A Mid-term Assessment of Progress Towards the Implementation of the Strategic Plan for Biodiversity 2011-2020. Secretariat for the Convention on Biological Diversity; 2014.

17. Karp DS, Tallis H, Sachse R, Halpern B, Thonicke K, Cramer W, Mooney H, Polasky S, Tietjen B, Waha K et al.: National indicators for observing ecosystem service change. Glob Environ Change 2015, 35:12-21.

18. Geijzendorffer IR, Martin-L6pez B, Roche PK: Improving the identification of mismatches in ecosystem services assessments. Ecol Indic 2015, 52:320-331.

19. Santini L, Belmaker J, Costello MJ, Pereira HM, Rossberg AG, Schipper AM, Ceauşu S, Dornelas M, Hilbers JP, Hortal J et al.: Assessing the suitability of diversity metrics to detect biodiversity change. Biol Conserv $2016 \mathrm{http}: / / \mathrm{dx} . \mathrm{doi} . \mathrm{org} /$ 10.1016/j.biocon.2016.08.024.

20. Schmeller DS, Weatherdon LV, Loyau A, Bondeau A, Brotons L, Brummitt N, Geijzendorffer IR, Haase P, Kuemmerlen M, Martin CS et al.: A suite of essential biodiversity variables for detecting critical biodiversity change. Biol Rev $2017 \mathrm{http}: / / \mathrm{dx} . \mathrm{doi} . \mathrm{org} /$ $10.1111 /$ brv.12332.

21. Schröter M, Albert C, Marques A, Tobon W, Lavorel S, Maes J, Brown C, Klotz S, Bonn A: National ecosystem assessments in Europe: a review. BioScience 2016 http://dx.doi.org/10.1093/ biosci/biw101.

22. Vihervaara P, Auvinen A-P, Mononen L, To“ rmâM, Ahlroth P, Anttila S, Bo“" ttcher K, Forsius M, Heino J, Helio“ lâJ et al.: How Essential Biodiversity Variables and remote sensing can help national biodiversity monitoring. Glob Ecol Conserv 2017, 10:4359.

23. Dymond J (Ed): Ecosystem Services in New Zealand: Conditions and Trends. Manaaki Whenua Press; 2013.

24. Millennium Ecosystem Assessment (Program) (Ed): Ecosystems and Human Well-Being: Synthesis. Island Press; 2005.

25. Santos-Martin F, Martin-L6pez B, Garcia-Llorente M, Aguado M, Benayas J, Montes C: Unraveling the relationships between ecosystems and human wellbeing in Spain. PLOS ONE 2013, 8: e73249.

26. United Nations: Transforming Our World: The 2030 Agenda for Sustainable Development, Document A/RES/70/1. United Nations; 2015.

27. Matthews GVT: The Ramsar Convention on Wetlands: Its History and Development. Ramsar Convention Bureau; 1993.

28. - Balvanera P, Caldéron-Contreras R, Castro AJ, Felipe-Lucia MJ, Geijzendorffer IR, Jacobs S, Martin-Lopez B, Arbieu U, Ifejika, Speranza C, Locatelli B et al.: Think globally, act locally: interconnected place-based social-ecological research isneeded to inform global sustainability. Curr Opin Environ Sustain 2017 http://dx.doi.org/10.1016/j.cosust.2017.09.005.

An innovative study that presents the important role and potential knowledge place-based research can offer to global biodiversity targets and highlights the current barriers to achieve this full potential.

29. •• Dicks LV, Walsh JC, Sutherland WJ: Organising evidence for environmental management decisions: a '4S' hierarchy. Trends Ecol Evol 2014, 29:607-613.

Authors successfully challenge the general assumption that improved scientific evidence automatically leads results in better informed policy decision making by including a decision maker's perspective.

30. Collen B (Ed): Biodiversity Monitoring and Conservation: Bridging the Gap Between Global Commitment and Local Action. John Wiley \& Sons Inc.; 2013.

31. Bomberg E: Environmental politics in the Trump era: an early assessment. Environ Polit 2017, 26:956-963.

32. Lubchenco J: Environmental science in a post-truth world. Front Ecol Environ 2017, 15:3.

33. IPBES: Work Programme of the Platform: Capacity-Building. 2017.

34. United Nations: Addis Ababa Action Agenda. United Nations; 2015.

35. Diaz S, Demissew S, Carabias J, Joly C, Lonsdale M, Ash N, Larigauderie A, Adhikari JR, Arico S, Bâldi A et al.: The IPBES Conceptual Framework - connecting nature and people. Curr Opin Environ Sustain 2015, 14:1-16.

36. Pereira HM, Ferrier S, Walters M, Geller GN, Jongman RHG, Scholes RJ, Bruford MW, Brummitt N, Butchart SHM, Cardoso AC et al.: Essential Biodiversity Variables. Science 2013, 339:277-278.

37. Lee H, Lautenbach S: A quantitative review of relationships between ecosystem services. Ecol Indic 2016, 66:340-351.

38. Raudsepp-Hearne C, Peterson GD, Tengo" M, Bennett EM, Holland T, Benessaiah K, MacDonald GK, Pfeifer L: Untangling the environmentalist's paradox: why is human well-being increasing as ecosystem services degrade? BioScience 2010, 60:576-589.

39. •-Addison PFE, Cook CN, de Bie K: Conservation practitioners' perspectives on decision triggers for evidence-based management. J Appl Ecol 2016, 53:1351-1357.

A particular useful study which aims to better understand which biodiversity information is actually used by practitioners in conservation management and at what moment this information should be available.

40. ••Joppa LN, O'Connor B, Visconti P, Smith C, Geldmann J, Hoffmann M, Watson JEM, Butchart SHM, Virah-Sawmy M, Halpern BS et al.: Filling in biodiversity threat gaps. Science 2016, 352:416-418.

A first global review of datasets and ongoing monitoring schemes on specific threats for biodiversity demonstrates a general knowledge gap on the trends of the drivers of biodiversity decline. 
41. Bingham H, Doudin M, Weatherdon L, Despot-Belmonte K, Wetzel F, Groom Q, Lewis E, Regan E, Appeltans W, Güntsch A et al.: The biodiversity informatics landscape: elements, connections and opportunities. Res Ideas Outcomes 2017, 3: e14059.

42. Groom Q, Weatherdon L, Geijzendorffer IR: Is citizen science an open science in the case of biodiversity observations? J Appl Ecol 2017, 54:612-617.

43. - Sayer J, Sunderland T, Ghazoul J, Pfund J-L, Sheil D, Meijaard E, Venter M, Boedhihartono AK, Day M, Garcia C et al.: Ten principles for a landscape approach to reconciling agriculture, conservation, and other competing land uses. Proc Natl Acad Sci U S A 2013, 110:8349-8356.

Authors provide ten practitioner endorsed principles for an integrated approach to manage landscapes for multiple environmental, social and economic objectives, emphasizing adaptive management, stakeholder involvement, and multiple objectives.

44. • Titeux N, Henle K, Mihoub J-B, Regos A, Geijzendorffer IR, Cramer W, Verburg PH, Brotons L: Biodiversity scenarios neglect future land-use changes. Glob Change Biol 2016, 22:2505-2515.

An increasing bias is identified in biodiversity scenarios development consisting of impacts of climate change being increasingly included, but a reduction of the inclusion of habitat fragmentation, despite the latter impacting biodiversity more severely.

45. Hoffmann L, Silberstein J: Luc Hoffmann, I'homme qui s'obstine à préserver la terre. Phébus; 2010.

46. Clarke RA, Stavins RN, Greeno JL, Bavaria JL, Cairncross F, Esty DC, Smart B, Piet J, Wells RP, Gray R et al.: The challenge of Going Green. Harv Bus Rev 1994. https://hbr.org/1994/07/ the-challenge-of-going-green.

47. Eisenstein M: Pesticides: seeking answers amid a toxic debate. Nature 2015, 521:S52-S55.

48. Legg CJ, Nagy L: Why most conservation monitoring is, but need not be, a waste of time. J Environ Manag 2006, 78:194-199.

49. Geijzendorffer IR, Targetti S, Schneider MK, Brus DJ, Jeanneret P, Jongman RHG, Knotters M, Viaggi D, Angelova S, Arndorfer M et al.: Editor's Choice: how much would it cost to monitor farmland biodiversity in Europe? J Appl Ecol 2016, 53:140-149.

50. Vermaat JE, Hellmann FA, van Teeffelen AJA, van Minnen J, Alkemade R, Billeter R, Beierkuhnlein C, Boitani L, Cabeza M, Feld CK et al.: Differentiating the effects of climate and land use change on European biodiversity: a scenario analysis. Ambio 2017, 46:277-290.

51. Kuemmerle T, Erb K, Meyfroidt P, Müller D, Verburg PH, Estel S, Haberl H, Hostert P, Jepsen MR, Kastner T et al.: Challenges and opportunities in mapping land use intensity globally. Curr Opin Environ Sustain 2013, 5:484-493.

52. Kok K, Patel M, Rothman DS, Quaranta G: Multi-scale narratives from an IA perspective: Part II. Participatory local scenario development. Futures 2006, 38:285-311.

53. van Soesbergen A, Arnell AP, Sassen M, Stuch B, Schaldach R, Go“ pel J, Vervoort J, Mason-D'Croz D, Islam S, Palazzo A: Exploring future agricultural development and biodiversity in Uganda, Rwanda and Burundi: a spatially explicit scenariobased assessment. Reg Environ Change 2017, 17:1409-1420. 